Інноватика у вихованні. Випуск 12. 2020.

\author{
УДК 378.015.31-17.022.1
}

DOI: $\underline{10.35619 / \text { iiu.v1i12.305 }}$

Гринькова Надія

кандидат педагогічних наук, доцент, доцент кафедри теорії і методики виховання Рівненського державного гуманітарного університету,

м. Рівне, Україна

ORCID: 0000-0002-5774-8699,

e-mail: nadiia.hrynkova@rshu.edu.ua

\title{
ДО ПРОБЛЕМИ ДУХОВНО-МОРАЛЬНОГО ВИХОВАННЯ СТУДЕНТІВ ПЕДАГОГІЧНИХ ЗАКЛАДІВ ВИЩОЇ ОСВІТИ
}

Анотація. У статті схарактеризовано зміст та особливості духовноморального виховання студентів педагогічних закладів вищої освіти, визначені вікові особливості студентської молоді, які необхідно враховувати у процесі організації їхнього духовно-морального становлення. Проведений аналіз сучасних нормативно-правових документів 3 питань освіти дав змогу констатувати, що важливою складовою особистої готовності до педагогічної діяльності $\epsilon$ низка морально-етичних вимог, які висуваються перед майбутніми педагогами. З'ясовано, що у процесі духовно-морального виховання відбувається становлення духовної, емоційної та світоглядної сфер людини на основі засвоєння загальнолюдських та національних морально-етичних цінностей. Визначено, що 3 цією метою потрібно, насамперед, забезпечити умови для прилучення студентської молоді до культури, традицій, цінностей українського народу. Констатовано, що важлива роль у процесі духовноморального становлення майбутніх педагогів належить викладачу, який має забезпечити професійне керівництво виховним процесом студента, інтегруючи його 3 фаховою підготовкою. Виокремлено три рівні організації духовноморального виховання студентської молоді: мікрорівень, мезорівень та макрорівень. Підкреслено, що важливе значення для духовно-морально виховання студентів відіграє волонтерська діяльність. Зроблено висновок про те, що організація духовно-морального виховання студентської молоді в закладах вищої освіти потребує трансформації та вдосконалення.

Ключові слова: духовність, духовно-моральне виховання, моральні якості, загальнолюдські цінності, ціннісне ставлення, студенти педагогічних закладів вищої освіти.

Постановка проблеми. Духовно-моральна сфера завжди була важливою для українського народу, оскільки є віддзеркаленням його багатовікового досвіду, системи цінностей, менталітету та неповторності. Проблема загострилася у зв'язку зі світовою пандемією, переходом на дистанційне навчання, а відтак, обмеження можливостей прямого впливу на формування духовності, вихованості дітей та молоді. У таких умовах соціальних, політичних та економічних реалій підготовка духовної, морально зрілої молоді набуває особливої актуальності та ваги.

Особливо це стосується майбутніх педагогів, головне призначення яких які покликані сіяти зерна правди, добра і справедливості, а для цього повинні самі 
вирізнятися високою моральністю. Як зазначено у сучасних нормативноправових документах, зокрема таких, як Закон України «Про вищу освіту» (2020), Концепція «Нова українська школа» (2016), Програма «Нова українська школа у поступі до цінностей» (2018), Концепція «Національного виховання студентської молоді» (2009) важливою складовою особистої готовності до педагогічної діяльності $\epsilon$ не лише освіченість, а й низка морально-етичних вимог: відповідальність, чесність, справедливість, гуманність, толерантність, працелюбність, комунікабельність, прагнення до постійного самовдосконалення.

Василь Олександрович Сухомлинський стверджував: «Головне, - це віра в людину, чутливість до всього хорошого в ній. Висока моральність учителя стає нині найважливішою умовою його педагогічної майстерності... Улюбленим i авторитетним учитель стає не тільки тому, що досконало знає свій предмет, а й тому, що, глибоко люблячи його, поєднує у своєму серці цю любов 3 любов'ю до людини-дитини» (Сухомлинський, 1977, с.15).

Отже, розгляд проблеми духовно-морального виховання студентської молоді 3 метою визначення ефективних шляхів його реалізації в умовах закладу вищої освіти є наразі актуальним і необхідним.

Аналіз останніх досліджень 3 проблеми. Проведений аналіз наукових джерел дає підстави для висновку про те, що проблема морального становлення особистості не є новою. Приміром, вона була предметом дослідження педагогів М. Монтесорі, С. Русової, К. Ушинського, А. Макаренка, В. Сухомлинського. Своєю чергою, філософські засади і передумови духовно-морального виховання молоді представлені в роботах А. Ахвердова, А. Гусейнова, Н. Бердяєва, Н. Крутова, А. Лопуховської, О. Целікової та інших.

У працях психологів Л. Виготського, Д. Ельконіна, С. Анісімова, І. Беха, Т. Ващенко, В.Гуріна, М. Іванчук, Д. Колесова, Н. Непомнящої, Р. Павелківа, розкрито психологічні механізми та закономірності духовного становлення особистості. Релігійна культура дітей та молоді стала предметом дослідження Л. Гризи, М. Романенко, Ю. Терещенко, Т. Тхоржеховської Л. Шугаєвої, які наголошували на необхідності впровадження навчального курсу християнської етики в закладах освіти. А. Бойко, Н. Лавриненко, В. Пащенко, Г. Опилат, Л. Орбан обгрунтували дефініцію понять «релігійна освіта» і «релігійне виховання».

На сучасному етапі розробку проблеми формування духовності здійснили Г. Сагач, . Зелінченко, О. Омельченко, О. Сухомлинська, Г. Шевченко, Л. Хоружа, О. Целякова та інші.

Отож, деякі аспекти актуалізованої проблеми знайшли висвітлення у різновекторних доробках вчених, однак досі немає системного дослідження організації освітнього процесу у педагогічних закладах вищої освіти щодо духовно-морального виховання сучасної студентської молоді.

У контексті вищезазначеного метою нашої статті $€$ визначення важливих аспектів духовно-морального виховання студентів - майбутніх педагогів.

Виклад основного матеріалу дослідження. Важливим у нашій науковій розвідці $\epsilon$ аналіз змісту поняття «духовність», «духовно-моральне виховання». Зокрема, у працях зарубіжних психологів, а саме: Е. Бартона, К. Роджерса, Р. Мейя, А. Швейцара, М. Шелера, К. Юнга духовність розуміється як загальнокультурний феномен, який відображає реальні дії та вчинки людей, що грунтуються на їхніх поглядах, переконаннях, світогляді. 
Своєю чергою, С. Гончаренко у педагогічному словнику дає таке визначення духовності: «індивідуальна вираженість у системі мотивів людини двох фундаментальних потреб: ідеальної потреби у пізнанні й соціальної потреби жити, діяти «для інших людей»...3 категорією «духовність» співвідноситься потреба пізнавати світ, самого себе, смисл і призначення свого життя. Людина $є$ духовною в тій мірі, в якій вона задумується над цими питаннями і прагне дістати на них відповідь. Втрата духовності $є$ рівнозначною втраті людяності. Формування духовних потреб особистості $\epsilon$ найважливішим завданням виховання» (Гончаренко, 1997).

Як свідчать наукові джерела, трактування поняття «духовність» розглядається у двох аспектах - релігійному та світському. Перше пов'язане 3 вірю в Бога та дотриманням його заповідей, друге передбачає духовне становлення особистості їі власними силами та можливостями. Спільним для обох наукових підходів є переконання в необхідності формування важливих моральних якостей: доброти, милосердя, справедливості, гуманності тощо. Отже, духовність $\epsilon$ внутрішнім стрижнем людини, виявом їі моральної сутності та рівня сформованості ставлення до навколишньої дійсності на основі загальнолюдських моральних цінностей.

Проаналізувавши дослідження І. Андрощука, Н. Волкової, В. Жуковського,

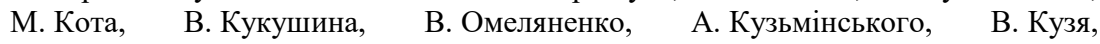
С. Мельничука, М. Фіцули дав зробити наступне узагальнення терміну «духовно-моральне виховання»: це цілеспрямований і свідомо організований процес морально-емоційного формування особистості, зокрема, іiі моральних якостей, моральних понять, уявлень, переконань, світогляду, ціннісного ставлення до себе та оточуючого світу, моральної поведінки.

Якщо ж апелювати до аксеологічного підходу, то ефективно організований процес духовно-морального виховання особистості передбачає орієнтацію на цінності, які зможуть задовольняти потреби людини та іiі особисті запити i можливості у певній соціальній ситуації.

У процесі духовно-морального виховання відбувається становлення духовної, емоційної та світоглядної сфер людини на основі засвоєння загальнолюдських та національних морально-етичних цінностей. На наш погляд, 3 цією метою потрібно, насамперед, забезпечити умови для прилучення студентської молоді до культури, традицій українського народу, формувати шанобливе ставлення до культурних надбань поколінь, народних цінностей тощо. При цьому дуже важливим $\epsilon$ також формування полікультурних міжетнічних відносин, гуманізму, толерантності. Визначені завдання можна зреалізувати шляхом врахування вікових та індивідуальних особливостей студентської молоді, а також побудовою ефективного освітнього духовного середовища в закладі вищої освіти (Бакуменко, 2017).

Навчання в університеті (17-25 років) - це період пізньої юності, або початок зрілості Він $є$ сенситивним для завершення формування психофізичних та особистісних якостей, набуття навичок виконання різних видів діяльності, здатності самостійно приймати життєво важливі рішення, соціалізовуватися в нових сфера суспільного життя тощо. У цьому віці особистість характеризується достатнім рівнем інтелектуального, емоційного, фізичного, соціальнокультурного розвитку, активним визначенням життєвої позиції та стратегії тощо. 
Зважаючи на вікові особливості студентської молоді, можна стверджувати, що маємо майже сформовану особистість. Тож, якщо хочемо щось змінити, то маємо сприяти процесу самовиховання, самовдосконалення студентів, що забезпечить можливості для формування нових рис характеру, звичок поведінки. 3 цією метою важливим є пошук ефективних форм, методів та прийомів впливу на студентів у закладі вищої освіти. Висвітлення окремих аспектів цієї проблеми знаходимо у працях В. Андрущенко, Т. Бакуменко, І. Гриценко, В. Лугового, Л. Москальової, І. Сіданича.

Як свідчить аналіз проведеного онлайн-опитування серед студентів другого та четвертого курсу педагогічного факультету Рівненського державного гуманітарного університету більшість респондентів (78\%) розуміють важливість духовного вдосконалення особистості майбутнього вчителя. 62 \% від загальної кількості опитаних готові до активних змін власної особистості і хочуть брати участь у заходах духовно-морального змісту, зокрема благодійних акціях, рейдах, просвітницькій діяльності. Отримані кількісні та якісні дані, на нашу думку, пов'язані із функціонуванням студентського волонтерського центру «Від серця до серця», учасники якого, відповідно, дали схвальні відгуки на питання анкети. Лише $38 \%$ опитаних студентів факультету документальних комунікацій та менеджменту на запитання анкети: «Чи маєте Ви бажання займатися благодійницькою діяльністю» відповіли схвально. Проаналізувавши відповіді студентів цього ж факультету на одне з перших запитань: «Що Ви розумієте під змістом поняття духовно-морально розвинена особистість», ми дійшли висновку, що більшість студентів (86\%) ототожнюють зміст цього поняття із моральними якостями (бути добрим, милосердним, чесним, справедливим тощо), а також пов'язують зі сповідуванням певної релігії. Натомість у відповідях не йдеться про конкретні позитивні вчинки і моральну поведінку особистості.

Дослідження проблеми духовно-морального виховання студентської молоді дає підстави зробити висновок про те, що цей процес буде ефективним за умови суб'єктної позиції вихованця, активної його участі в житті університету, навчально-пізнавальних, творчо-пошукових, дослідницьких, благодійних, дозвіллєвих та інших заходах. Важлива роль у процесі духовно-морального становлення майбутніх педагогів належить викладачу, який має забезпечити професійне керівництво виховним процесом студента, інтегруючи його 3 фаховою підготовкою.

Ми умовно виокремили рівні організації духовно-морального виховання студентської молоді: мікрорівень, мезорівень та макрорівень.

На мікрорівні необхідно організувати освітню діяльність студентів, включаючи у зміст навчальних дисциплін проблеми становлення професійно значущих духовно-моральних якостей, системи цінностей та ціннісних орієнтацій, сприяти ознайомленню 3 цими категоріями та аргументувати їх необхідність. Водночас важливо створювати виховні ситуації, які б сприяли формуванню вмінь робити вибір духовно-моральних цінностей, аби вони співвідносилися 3 індивідуальними та професійними потребами, а також відповідали національній культурі та ідеалам.

Реалізація мезорівня, насамперед, передбачає створення ефективної та гнучкої системи духовно-морального виховання на рівні університету; при цьому важливо забезпечити процес управління як 3 боку професорськовикладацького складу, так i самих студентів. Важливо систематично 
реалізовувати виховні заходи із залученням студентської молоді всього закладу вищої освіти: проведення марафонів, створення веб-сторінок, радіо та теле інформаційних каналів, відзначення пам'ятних подій, дат, організація зустрічей з видатними людьми, активна участь у благодійній діяльності в університеті та поза ним тощо. Важливе значення у такому процесі відіграє волонтерська дяльність: створення благодійний центрів, клубів, тощо (Гринькова, Стельмашук, Ваколюк, 2020).

На макрорівні, на наш погляд, духовно-моральне виховання студентської молоді необхідно зорганізувати залучивши студентів до заходів, подій, марафонів на державному рівні. Важливу роль у цьому відіграють також молодіжні громадські товариства та організації. До прикладу, Асоціація Гайдів України, Асоціація трудових об'єднань молоді України, асоціація молодіжного співробітництва «Альтернатива-В», громадське об'єднання «Нова Генерація», молодіжна громадська організація Клуб міжнародного співробітництва «Мандри», Всеукраїнська студентська рада, громадська організацій «Скаути України», громадська організація «СПОК», молодіжна організація «Сяйво», молодіжна громадська організація «Молодий Рух», молодіжна громадська організація «Молодь третього тисячоліття» тощо.

Зазначимо, що ефективність духовно-морального виховання студентів педагогічних закладів вищої освіти залежить від створення мотиваційної основи, підгрунтя для формування духовності, підготовки та рівня духовної культури самих викладачів, вдало організованої виховної системи закладу вищої освіти на усіх рівнях, ефективне залучення інших соціальних інституцій, установ, культурно-розважальних закладів, засобів масової інформації до становлення морально-розвиненої особистості. Саме це сприятиме підняттю рівня духовності кожної особистості в державі та нації в цілому.

Висновки і перспективи подальших розвідок. Отже, організація духовноморального виховання студентської молоді в закладах вищої освіти потребує трансформації та вдосконалення і є системним, послідовним й багатоаспектним процесом. Про це свідчить проведене дослідження, у тому числі онлайопитування студентів. Перспективами подальших наукових розвідок є розробка практичних способів реалізації презентованих аспектів на рівні закладу вищої освіти: перспективних шляхів вдосконалення виховної системи студентів, а також технології духовно-морального становлення сучасної студентської молоді 3 урахуванням національного контенту та сучасних суспільних умов.

\section{СПИСОК ВИКОРИСТАНИХ ДЖЕРЕЛ}

Міністерство освіти і науки України. (2020). Закон Украӥни «Про вищу освіту». URL: https://zakon.rada.gov.ua/laws/show/1556-18\#Tехt_[Дата останнього звернення 05 жовтня 2020].

Кабінет Міністрів України. (2016). Концеепчія «Нова українська икола». URL: https://mon.gov.ua/ua/tag/nova-ukrainska-shkola [Дата останнього звернення 5 жовтня 2019].

Інститут проблем виховання, Інститут модернізації змісту освіти. (2018). Програма «Нова українська школа» у поступі до изіностей. Київ. 40 с.

Кабінет Міністрів України. (2009). Конщ̧епція національного виховання студентської молоді. URL: http: // ru.osvita.ua/legislation/Vishya_osvita/4310 [Дата останнього звернення 5 жовтня 2020]. 
Сухомлинський, В. (1977). Вибрані твори в 5 m. Т.4: Павлиська середня школа. Розмова з молодим директором. Київ: Радянська школа. 640 с.

Гончаренко, С. (1997). В: Педагогічний словник. Київ: Либідь, с.370

Бакуменко, Т. Окремі аспекти духовно-морального виховання студентів педагогічних ВНЗ. Духовність особистості: метологія і практика. 1, сс. 6-12.

Гринькова, Н., Стельмашук, Ж., Ваколюк, А. (2020). Роль волонтерської діяльності у формуванні особистості майбутнього вчителя початкової школи. Інноватика у вихованні. 11(2), сс. 93-102.

\section{REFERENCES}

Ministry of Education and Science of Ukraine. (2020). Zakon Ukrayini «Pro vyshchu osvitu» [A law of Ukraine is «On higher education»]. URL: https://zakon.rada.gov.ua/laws/show/1556-18\#Text [Data ostanoho zvernennia 5 zhovtnia 2020]. [in Ukrainian]

Cabinet of Ministers of Ukraine. (2016). Kontseptsiia «Nova ukrainska shkola» [Conception «New Ukrainian school»]. URL: https://mon.gov.ua/ua/tag/novaukrainska-shkola [Data ostanoho zvernennia 5 zhovtnia 2020]. [in Ukrainian]

Institute of problems of education, Institute of modernisation of education. (2018). Prohrama Nova ukrainska shkola u postupi do tsinnostei. [Program New Ukrainian school in moving toward values]. Kyiv. [in Ukrainian]

Cabinet of Ministers of Ukraine. (2006). Kontseptsiia natsionalnoho vykhovannia studentskoi molodi [The concept of national education of student youth]. URL: // http://ru.osvita.ua/legislation/Vishya_osvita/4310/ [Data ostanoho zvernennia 5 zhovtnia 2020]. [in Ukrainian]

Sukhomlynskyi, V. (1977). Vybrani tvory: Vol. 4 [Selected Works]. Kyiv: Radianska shkola. [in Ukrainian]

Honcharenko, S. (1997). Pedahohichnyi slovnyk [Pedagogical dictionary]. Kyiv: Lybid. s. 370. [in Ukrainian]

Bakumenko, T. (2017). Okremi aspekty dukhovno-moralnoho vykhovannia studentiv pedahohichnykh VNZ. [Some aspects of spiritual and moral education of students of pedagogical universities]. Dukhovnist osobystosti: metolohiia i praktyka]. No1. s. 6-12. [in Ukrainian]

Hrynkova, N., Stelmashuk, Zh. \& Vakoliuk, A. (2020). Rol volonterskoi diialnosti $\mathrm{u}$ formuvanni osobystosti maibutnoho vchytelia pochatkovoi shkoly [The role of volunteering in shaping the personality of the future primary school teacher]. Innovatyka u vykhovanni [Innovation in education], 11, s. 93-102. [in Ukrainian]

\section{TO THE PROBLEM OF SPIRITUAL AND MORAL EDUCATION OF STUDENTS OF PEDAGOGICAL UNIVERSITIES}

Nadiia Hrynkova

Candidate of Pedagogical Sciences, Associate Professor Associate Professor at the Department of Theory and Methods of Education,

Rivne State University for the Humanities ORCID: 0000-0002-5774-8699 e-mail: nadiia.hrynkova@rshu.edu.ua 


\begin{abstract}
The article deals with the spiritual and moral education of students of pedagogical institutions of higher education. The age characteristics of student youth, which must be taken into considerationt in the process of organizing their spiritual and moral development is identified. The analysis of modern legal documents on education allowed us to conclude that an important component of personal readiness for teaching is a number of moral and ethical requirements for future teachers.

It was found that in the process of spiritual and moral education the formation of spiritual, emotional and ideological spheres of man on the basis of the assimilation of universal and national moral and ethical values takes plsce. It was determined that for this purpose it is necessary, first of all, to provide conditions for the involvement of student youth in the culture, traditions of the Ukrainian people, to form a respectful attitude to the cultural heritage of generations, national values. It was stated that an important role in the process of spiritual and moral development of future teachers belongs to the teacher, who should provide professional guidance to the educational process of the student, integrating it with professional training. There are three levels of organization of spiritual and moral education of student youth: micro-level, mesolevel and macro-level. At the micro level it is necessary to organize the educational activities of students, including in the content of academic disciplines the problems of formation of professionally significant spiritual and moral qualities, value systems and value orientations. The implementation of the meso level involves the creation of an effective and flexible system of spiritual and moral education at the university level. At the macro level, it is necessary to involve students in events, marathons at the state level. Youth societies, associations, and organizations play an important role in this. It is emphasized that volunteering is important for the spiritual and moral education of students. It is concluded that the organization of spiritual and moral education of student youth in higher education institutions needs transformation and improvement.

Key words: spirituality, spiritual and moral education, moral qualities, universal values, values, students of pedagogical universities.
\end{abstract}

Стаття надійшла до редакиї 08. 10.2020 р. 